\title{
Article \\ Construction Waste Audit in the Framework of Sustainable Waste Management in Construction Projects-Case Study
}

\author{
Marcela Spišáková, Peter Mésároš and Tomáš Mandičák *iD \\ Faculty of Civil Engineering, Technical University of Košice, Vysokoškolská 4, 04200 Košice, Slovakia; \\ marcela.spisakova@tuke.sk (M.S.); peter.mesaros@tuke.sk (P.M.) \\ * Correspondence: tomas.mandicak@tuke.sk; Tel.: +421-55-602-4378
}

Citation: Spišáková, M.; Mésároš, P.; Mandičák, T. Construction Waste Audit in the Framework of Sustainable Waste Management in Construction Projects-Case Study. Buildings 2021, 11, 61. https://doi. org/10.3390/buildings11020061

Academic Editor:

Francesco Colangelo

Received: 10 December 2020

Accepted: 5 February 2021

Published: 11 February 2021

Publisher's Note: MDPI stays neutral with regard to jurisdictional claims in published maps and institutional affiliations.

Copyright: (c) 2021 by the authors. Licensee MDPI, Basel, Switzerland. This article is an open access article distributed under the terms and conditions of the Creative Commons Attribution (CC BY) license (https:// creativecommons.org/licenses/by/ $4.0 /)$.

\begin{abstract}
The issue of sustainability has long been the subject of interest in architecture engineering and the construction sector. All three aspects of sustainability-economic, environmental, and socialcan be affected through appropriate construction waste management. Construction and demolition waste $(\mathrm{CDW})$ is one of the largest worldwide waste streams, therefore, it is given great attention by all stakeholders (investors, contractors, authorities, etc.). Research studies show that one of the main barriers to insufficient CDW recovery is inadequate policies and legal frameworks to manage CDW. It is also one of European Union's (EU) environmental priorities. The aim of the article was to confirm the economic potential of construction and demolition waste audit processing through a case study. A pre-demolition waste audit was processed for an unused shopping center building in the town Snina in Slovakia. Subsequently, a comparison of economic parameters (waste disposal costs and transport costs) of the recommended CDW management was performed. This comparison confirmed the economic benefits of environmentally friendly construction waste management methods according to the waste audit results, which would also increase the sustainability of construction projects. Additionally, the cost parameters of selected waste disposal methods could be another dimension of building information modeling.
\end{abstract}

Keywords: construction and demolition waste; renovation; demolition; waste disposal; pre-renovation audit; waste audit; construction; comparison; costs

\section{Introduction}

Architecture engineering and construction (AEC) belongs to an important part of the European Union (EU) economy. AEC activities contribute to about 10\% of GDP in the European Union and create 20 million jobs [1]. At the same time, AEC is responsible for around half of all extracted material, half of the total energy consumption, a third of waste generation, and a third of water consumption [2,3]. Construction and demolition activities create the biggest worldwide waste stream-36\% solid waste produced in Europe [4,5], about $60 \%$ waste produced in the United States [6], and 30-40\% waste in China [7]. Construction and demolition waste (CDW) arise from construction works, securing works, as well as the works performed during maintenance of constructions, modification of constructions, or removals of constructions. CDW consists of many materials including masonry, concrete, metal, asphalt, wood, gypsum, glass, plastic, and excavated soil [8]. Hazardous substances (asbestos, PCBs, etc.) are also part of CDW. Hazardous waste might generate an increased risk to the environment and the human health if not managed and disposed safely. CDW is usually used as a substitute for natural material in road construction, for backfilling or landscaping, or for landfilling or incineration [2]. The most significant construction and demolition waste streams are mixed concrete and masonry waste, bituminous mixtures; a smaller waste stream is gypsum [9]. Recovered CDW can successfully serve as a substitute for raw materials. Concrete and masonry waste has a huge potential for recycling. Unfortunately, the backfilling is the most common scenario of its application. Recovery of concrete 
and bricks often consists of homogenization and crushing. Crushed recycled concrete and bricks are suitable for use as aggregate in unbound layers in roads and parking, in concrete production, and final cover material as a drainage layer. The recovery rate for concrete and masonry waste generated only from building activities is about $80 \%$. It is estimated that $25 \%$ of the total production of new concrete mixes are recovered [9-11]. Recovered bituminous mixtures (asphalt) can be re-used in new asphalt mixture, in the next surface, as recycled aggregate in unbound road layers, and finally as unspecified filling material. The statistical data on recovered asphalt is not listed, but it is possible to estimate that $10-20 \%$ of the total production of new asphalt mixes are recovered. Gypsum-based waste is a small waste flow. Recycled gypsum is useful for the production of gypsum powder for use in the manufacture of plasterboard and stucco, as a raw material in cement production, as a nutrient and a structural material in compost/agriculture soil treatment $[10,11]$.

A significant amount of construction and demolition waste has a great potential for re-use and recycling [12]. This recovery performance of CDW is not fully used in all countries of the European Union. In 2018, recovery rate of construction and demolition waste in EU was 90\% [13]. Recovery rate between EU member states differed significantly from one country to another (Figure 1). The recovery potential was fully applied (more than $90 \%$ ) in countries like The Netherlands, Ireland, Malta, Hungary, Lithuania, Italy, Luxembourg, Slovenia, Belgium, Denmark, Greece, Estonia, Germany, Portugal, Czech Republic, Austria, and United Kingdom. On the other side, member states like Bulgaria and Slovakia (24\% and 51\%) do not use the full recovery potential of CDW [13].

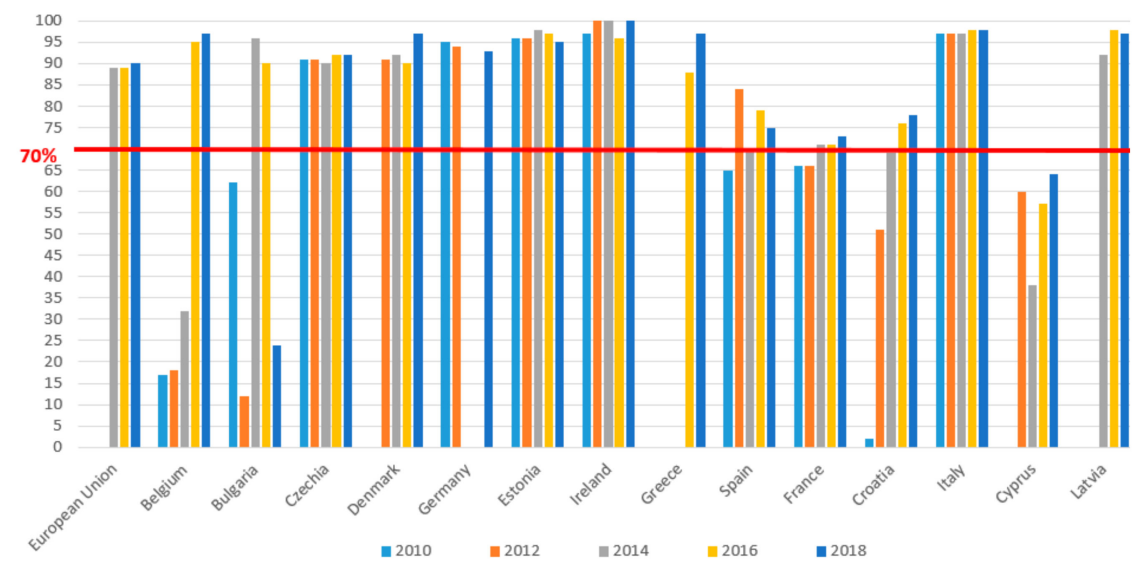

(a)

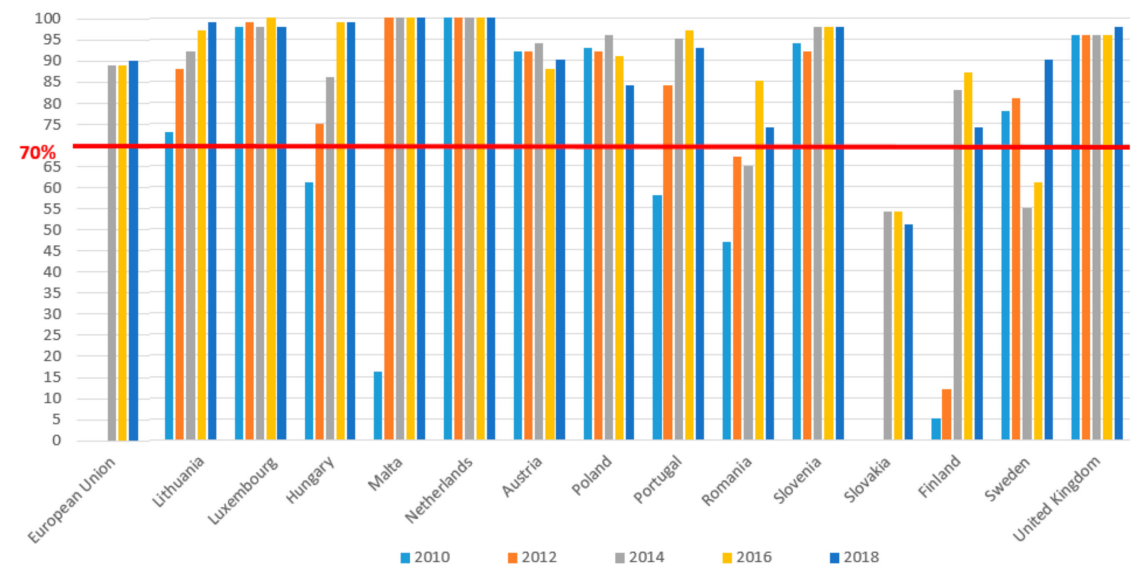

(b)

Figure 1. Recovery rate of construction and demolition waste in EU member states in the period 2010-2018, (a) EU, Belgium-Latvia, (b) EU, Lithuania--United Kingdom [13] (Eurostat, 2020). 
The target of European Union according to The Waste Framework Directive 2008/98/ European Commission (EC) is to have $70 \%$ of CDW re-used, recycled, or recovered by 2020 [14]. Most member states of EU already met this target as early as 2018. In many states, it is still an opportunity to improve their approach to construction waste recovery. EU in 2016 processed the document "EU Construction \& Demolition Waste Management Protocol" [15], which contributed to reaching a target of 70\% of CDW to be recycled by 2020 . This should be achieved through-(i) improved waste identification, source separation, and collection; (ii) improved waste logistics; (iii) improved waste processing; (iv) quality management; and (v) appropriate policy and framework conditions [15]. Unfortunately, there are still many barriers that prevent the recovery of construction and demolition waste from the point of stakeholders' view.

\section{Literature Review}

\subsection{Barriers to Improving the Environmental Performance of Construction Waste Management}

Environmental performance of construction and demolition waste management is affected by many factors. Many studies described these effects from many points of view. Author Mahphour [16] summarized the potential barriers to moving toward circular economy in CDW management. The authors of the study in [17] focused on the description of barriers in terms of waste management strategy; the study in [18] divided the barriers into six groups-financial/economic, institutional, environmental, technical, socio-cultural, and legal/policy. The summary of barriers to increasing CDW recycling and re-using was processed based on its analysis [16-37]. The studied barriers were divided into four barriers group-environmental (Table 1), economic (Table 2), social (Table 3), and legal/policy (Table 4). Some barriers cannot be included in a particular group; they belong to several groups by their nature at the same time. The individual barriers mutual interact.

Table 1. Summary of environmental barriers to increasing construction and demolition waste (CDW) recycling and re-using.

\begin{tabular}{|c|c|}
\hline Potential Barrier & Source \\
\hline ineffective CDW dismantling, sorting, transporting, and recovering processes & {$[17,19,32]$} \\
\hline $\begin{array}{l}\text { not green designing of construction projects-waste reduction does not receive sufficient } \\
\text { attention in building planning and design }\end{array}$ & {$[19,35]$} \\
\hline using finitely recyclable construction materials & [19] \\
\hline $\begin{array}{l}\text { overemphasizing recycle and non-environment friendly methods during the construction and } \\
\text { demolition phases of construction projects }\end{array}$ & [20-23] \\
\hline preferring off-site CDW sorting/landfilling over on-site sorting due to lack of incentives & {$[21,24,25]$} \\
\hline lack of producer-based responsibility system in the production of construction materials & {$[28,29]$} \\
\hline inherent complexity of transforming to a circular economy in $\mathrm{CDW}$ management & {$[22,29]$} \\
\hline inadequate awareness, understanding, and insight into circular economy in CDW management & {$[17,21,29]$} \\
\hline inherent complexity of transforming to circular economy in CDW management & {$[22,29]$} \\
\hline lack of integration of sustainable CDW management & [29] \\
\hline uncertain aftermaths of moving toward circular economy in CDW management & {$[26,29]$} \\
\hline assumption that waste generation is inevitable and cannot be reduced & [17] \\
\hline design not using standard-sized materials & [17] \\
\hline lack of certainty about CDW condition & {$[17,32]$} \\
\hline
\end{tabular}

Table 2. Summary of economic barriers to increasing CDW recycling and re-using.

\begin{tabular}{|c|c|}
\hline Potential Barrier & Source \\
\hline lack of funding to implement circular economy in CDW management & [26] \\
\hline tendency to manage cost and time rather than CDW & {$[24,27]$} \\
\hline traditional construction methods & {$[17,33]$} \\
\hline cost of recycling processes-construction price does not reflect the environmental cost & {$[18,32]$} \\
\hline lack of time/time needed for material separation & {$[17,18]$} \\
\hline limited budget/costs of material separation & [17] \\
\hline lack of contractual requirement for reusing materials & [17] \\
\hline reluctance to segregate for recycling and re-using materials with a low economic value or difficult to reuse & [34] \\
\hline perception that waste reduction activities are not cost-effective, & [34] \\
\hline financial benefits from waste reduction are inequitably distributed, providing little incentive for operatives & [34] \\
\hline
\end{tabular}


Table 3. Summary of social barriers to increasing CDW recycling and re-using.

\begin{tabular}{cc}
\hline Potential Barrier & Source \\
\hline $\begin{array}{c}\text { lack of empirically-based literature on the barriers } \\
\text { undeveloped individuals' engagement } \\
\text { constructor's attitude }\end{array}$ & {$[21,28,29]$} \\
{$[20,26]$} \\
user preference for new construction materials over reused/recycled ones & {$[17]$} \\
construction industry culture & {$[21,26]$} \\
mack of commitment by top urban managers to move toward circular economy in CDW & {$[20,26]$} \\
first priority is financial profit and not environmental issues & {$[17]$} \\
ineffective CDW management & {$[17,18]$} \\
lack of a well-developed waste recycling market & {$[32]$} \\
the building users do not participate in the planning and design process & {$[32,33]$} \\
low demand by clients for sustainable buildings & {$[37]$} \\
difficulties in changing work practices of workforce & {$[35]$} \\
a belief that waste reduction efforts will never be sufficient to completely eliminate waste & {$[33]$} \\
\hline
\end{tabular}

Table 4. Summary of legacy/policy barriers to increasing CDW recycling and re-using.

\begin{tabular}{cc}
\hline Potential Barrier & Source \\
\hline inadequate policies and legal frameworks to manage CDW as well as lack of & supervision on CDW management \\
lack of clearly defined national goals, targets, and visions to move toward circular & {$[17,21,26-28,32,33,37]$} \\
economy in CDW management & {$[20,25,30]$} \\
non-standardized CDW reduction reporting as well as lack of accessible data & {$[18,20]$} \\
lack of financial incentive & {$[17]$} \\
lack of coordination among divisions & {$[35]$} \\
inconsistencies between different governmental agencies & {$[34]$} \\
absence of industry norms or performance standards for managing waste & {$[34]$}
\end{tabular}

\subsection{Construction and Demolition Waste Audit}

The barriers to the adoption of the construction waste recycling and re-using are different. Lack of clear and mandatory requirements for CDW management was identified as one of the most significant barriers to CDW recovery. In many cases, the stakeholders are interested in CDW management, but there are still some challenges to the construction sector. For example, valuable materials are not always identified, collected separately, or adequately recovered [4]. Therefore, EU decided to create EU waste audit guideline [38] for managing $\mathrm{CDW}$, which sets out the procedure for construction and demolition waste management, defines the stakeholders and their tasks, and provides waste management recommendations. Document (called "waste audit" or "pre-demolition audit") is focused on the assessment of CDW streams prior to the renovation of the demolition of constructions.

Audit of construction and demolition waste (CDWA) should be an integral part of each construction project, mainly demolition and renovation. The valid and proper CDWA was to be processed by a qualified expert (authorized auditor). Authors of study [39] determined the mandatory pre-demolition and renovation audit as the most promising measures, which impact the environmental and socio-economic field of CDW management. This is also confirmed by best practices from many member states of EU [38-40]. CDWA is not specified by a common framework across the EU. Compliance with the document is not mandatory, but its adoption will significantly increase the rate of construction waste recovery. In many member states of EU, CDWA is required due to the key CDW policy and legislation for any type of construction waste or only for hazardous waste. On the other hand, in some states, there is no legislative obligation of CDWA (Table 5). Legislative requirements for CDWA are usually part of the permission for demolition or renovation of building. 
Table 5. Legislative obligation for construction and demolition waste audit [38-40].

\begin{tabular}{cc}
\hline Legislative Obligation & Member State of EU \\
\hline mandatory audit & Belgium, Bulgaria, Czech Republic, Finland, France, \\
& Italy, Luxembourg, Malta, Spain, Sweden, The \\
Netherlands, United Kingdom & Hungary, Ireland, Poland, Slovenia \\
mandatory audit (only hazard CDW) & Austria, Croatia, Cyprus, Denmark Estonia, \\
no legislative obligation & Germany, Greece, Latvia, Lithuania, Portugal, \\
& Romania, Slovakia \\
\hline
\end{tabular}

The pre-demolition audit of CDW should be carried out before the renovation and demolition works. The demolition works supplier can identify and sort the demolition waste directly at the source based on audit results. The contractor of demolition works can identify and separate the CDW directly on the construction site. Pre-demolition audit of construction and demolition waste is an important driver to increase the recovery rate of construction and demolition waste, according to Waste Framework Directive 2008/98/EC [14].

\section{Materials and Methods}

The aim of the article was to confirm the economic potential of construction and demolition waste audit processing through a case study.

\subsection{Research Material}

An object of the case study is the unused shopping center building in the town of Snina in Northeastern Slovakia (Figure 2). The owner of the building decided to carry out the renovation works. The purpose of the construction changed. The building is to be used for administrative purposes.

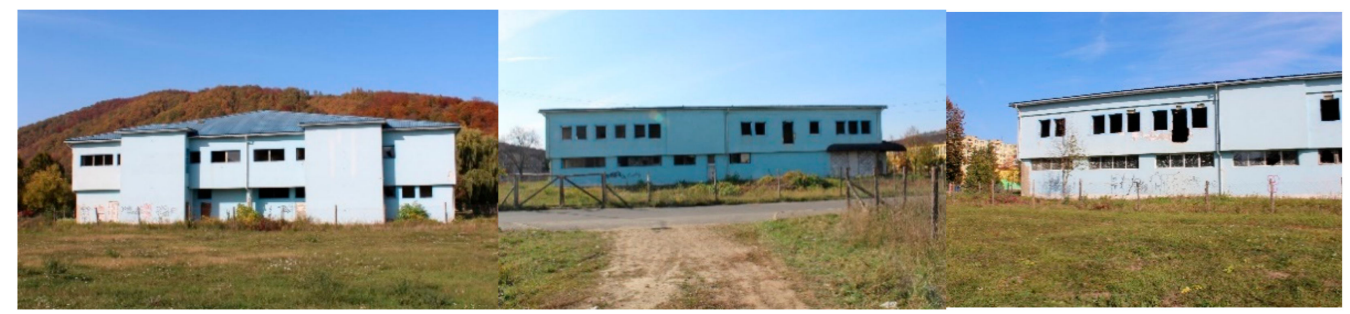

(a)

(b)

(c)

Figure 2. Building of the shopping center in Snina: (a) Southern view; (b) Eastern view; and (c) Northern view.

The load bearing system of the construction is a reinforced concrete frame skeleton in modular coordination $6 \times 6 \mathrm{~m}$. Slabs are made of prefabricated reinforced concrete Spiroll panels. The vertical communication system is secured by the existing reinforced concrete stairs, the lift shaft is not used, and the roof construction is hipped with timber roof truss.

Demolition works are to be carried out due to the unsatisfactory technical and static condition of the structure. They are part of the reconstruction of the building. Demolition works are focused on:

- Complete demolition of the non-load-bearing exterior cladding.

- Complete demolition of the internal non-load-bearing partition walls.

- Complete demolition of internal stairs and lift shafts.

- Increasing the depth of the foundation slab because of the installation of new lift shafts and escalators.

- Demolition of a part of the roof because of the construction of a new roof structure.

- Reduction of the wooden roof truss overlap around the perimeter of the building.

- Drilling holes in Spiroll slabs because of the new communication system. 
- Demolition works are to be carried out downwards, from the roof structure to the foundations.

\subsection{Research Methods}

\subsubsection{Construction and Demolition Waste Audit}

Pre-demolition audit of construction and demolition waste should be carried out before renovation or demolition works begins. The methodology (Figure 3) of its processing is recommended according to "Guidelines for the waste audits before demolition and renovation works of buildings" [38]. The document sets out the content of the individual steps.

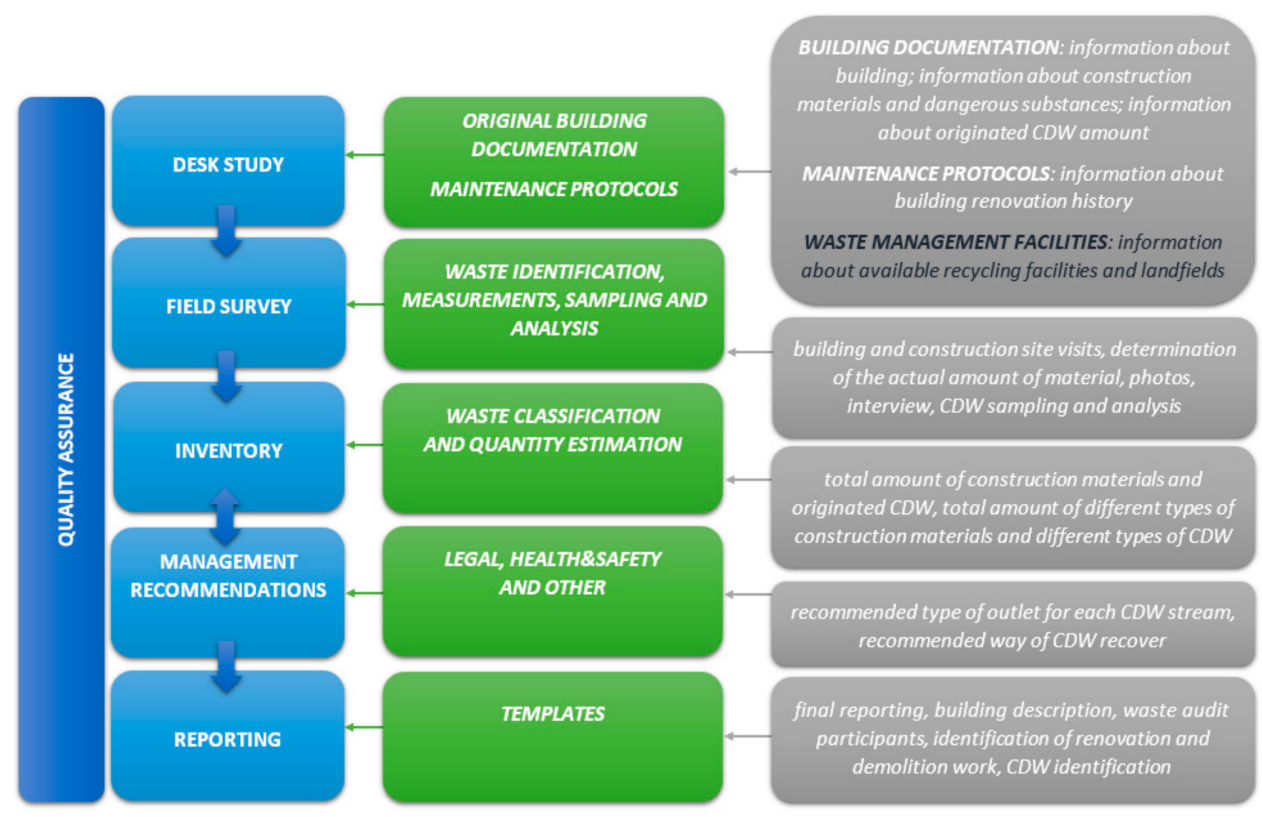

Figure 3. Scheme of the construction and demolition waste audit steps.

The result of the CDWA is a report identifying the construction and demolition waste stream that originated during the renovation or demolition works; and disposal options considering the building location. Desk study is focused on studying all available information about a specific building that is found in the project documentation of the renovated or demolished building-information on the load bearing system of the construction, information on construction elements and materials, information on dangerous substances, information on originated CDW amount, and information on the renovation history. Information is given mainly in the technical report of the construction project by the designer. CDW data that are often determined only by expert estimates, might not be accurate. Desk study of available recycling facilities and landfills in the building location was added beyond the recommended procedure of the CDWA, because of future economic analysis of waste management. This obtained information represents the input to proper CDWA. Another step of CDWA is field survey, which involves a visit to the construction site and the particular building. All rooms of building are visually inspected during this visit. A detailed inventory of construction material for each room and construction elements (slabs, roof, columns, etc.) is processed. The aim of this step is to obtain measurements or confirm the data obtained during the desk study. If necessary, samples are taken for analysis. All obtained information should be complemented with photographs and confirmed by interviews.

Previous steps focused on buildings and construction materials. The inventory of materials and elements determined the amount and type of construction waste that originates during renovation or demolition work. Inventory of materials and originated CDW should be developed separately for each room, with the minimum required set of data for 
the whole building. Quantified and qualified data on generated waste have an impact on waste management recommendation; and is necessary for the decision-making process of the appropriate CDW recovery method, in terms of technical and economic aspects. The final report involved essential, mandatory, and optional information. The final report must contain essential information about construction project, location, stakeholders, total amount of CDW, a summary of hazardous waste, and description of the waste treatment methodology. The mandatory information of the report involves the construction materials inventory. These data could be-(i) basic (hazardous/non- hazardous CDW), (ii) intermediate (hazardous/non-hazardous CDW (non-inert)/ non-hazardous CDW (inert)), and (iii) type of material + waste code (according European List of Waste [41]). The construction elements inventory is not mandatory. The last point of CDWA is waste management recommendations that present an optional result.

\subsubsection{Economic Analysis of Construction and Demolition Waste Disposal}

The economic potential of a sustainable approach to CDW management is demonstrated through the calculation of costs for waste treatment and costs of waste transport for two variants:

- Variant " $\mathrm{A}$ " presents the waste management according to CDWA recommendation.

- Variant "B" presents the least environment-friendly method of waste management, namely landfilling of the whole amount volume of waste.

The economic comparison of the proposed variants focuses on the analysis costs for waste disposal and transport costs. Waste disposal costs are expressed using the following equation, Equation (1):

$$
C_{w d}=\sum_{i=1}^{n} Q_{i} \times F D_{i j}(€)
$$

where

- $C_{w d}$-costs for waste disposal (€)

- $\quad Q_{i}$-volume of $i$-th waste type $(\mathrm{t})$

- $\quad F D_{i j}$-fee for $j$-th waste disposal method of $i$-th waste type $(€ / t)$

- $\quad i$-waste type

- $\quad j$-waste disposal method

Transport costs depend on a number of transport kilometers and transport fee. They are expressed by the following equation, Equation (2):

$$
C_{t}=\sum_{i=1}^{n} n_{i j} \times F T_{i j}(€)
$$

where

- $C_{t}$-transport costs $(€)$

- $\quad n_{i j}$-the number of kilometers for the transport of the total amount of $i$-th waste to the $j$-th waste disposal site $(\mathrm{km})$

- $\quad F T_{i j}$-fee for transport $i$-th waste type to $j$-th waste disposal site $(€ / \mathrm{km})$

- $\quad i$-waste type

- $\quad j$-waste disposal method

The number of transport kilometers relates to distance of waste generation site to waste disposal site and number of rides between these two sites through Equation (3):

$$
n_{i j}=\sum_{i=1}^{n} D_{i j} \times n r_{i j} \times 2(\mathrm{~km})
$$

where

- $\quad n_{i j}$-the number of kilometers for the transport of the total amount of $i$-th waste to the $j$-th waste disposal site $(\mathrm{km})$

- $\quad D_{j}$-distance of the waste generation site for $i$-th waste type to the $j$-th waste disposal site $(\mathrm{km})$ 
- $n r_{i j}$-number of rides from $i$-th waste type to the $j$-th waste disposal site waste type (pcs)

- $\quad i$-waste type

- $\quad j$-waste disposal method

- 2-return distance coefficient

The number of rides related to truck transport volume, which is used for waste transport of $i$-th waste type to the $j$-th waste disposal site waste type. The number of rides is determined by rounding up from 0.3 by Equation (4):

$$
n r_{i j}=\sum_{i=1}^{n} \frac{Q_{i}}{Q_{v}}(\mathrm{pcs})
$$

where

- $\quad n r_{i j}$-number of rides from $j$-th waste disposal site to the waste generation site for $i$-th waste type (pcs)

- $\quad Q_{i}$-volume of $i$-th waste type $\left(\mathrm{m}^{3}\right)$

- $\quad Q_{v}$-volume of truck $\left(\mathrm{m}^{3}\right)$

- $\quad i$-waste type

- $\quad j$-waste disposal method

\section{Results and Discussion}

Construction and demolition waste audit before demolition and renovation works were implemented for the shopping center building in the Snina town. Considering that the object of CDWA is also the object of a case study, more detailed information about this building and renovations and demolition work is given in the Research Material section. An initial step of CDWA is the desk study (Figure 4).

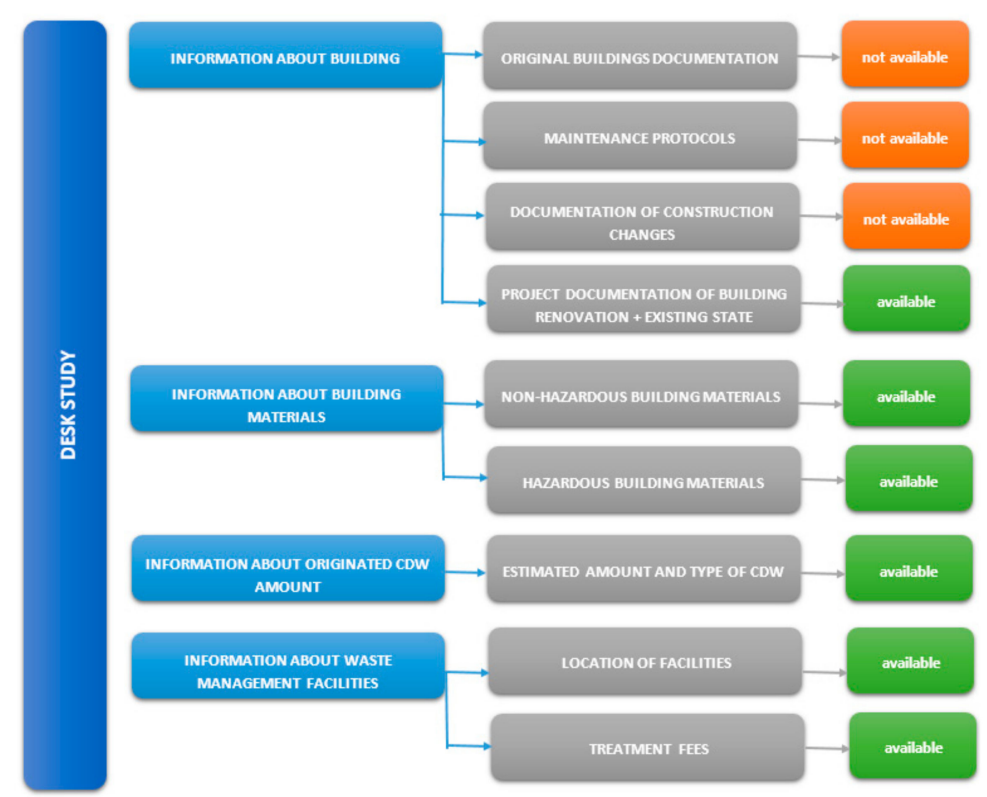

Figure 4. Steps of desk study for construction and demolition waste audit.

An original building documentation, maintenance protocols, and documentation of construction changes were not available. The only relevant document was the project documentation of designed building renovation and actual state. The project provides information about current building material types (non-hazardous/hazardous) and estimated amount and type of CDW (Table 6). 
Table 6. Estimated amount of construction and demolition waste according to project documentation.

\begin{tabular}{cccc}
\hline Waste Code & Type & Amount (t) & Category \\
\hline 170103 & tiles and ceramics & 1.5 & non-hazardous \\
170107 & mixtures of concrete, bricks, tiles, and ceramics other & 45.0 & non-hazardous \\
170201 & than those mentioned in 17 01 06 & 1.0 & non-hazardous \\
170202 & good & 2.0 & non-hazardous \\
170405 & iron and steel & 1.2 & non-hazardous \\
170411 & cables other than those mentioned in 17 04 10 & 0.05 & non-hazardous \\
170504 & non-hazardous \\
170904 & $\begin{array}{c}\text { mixed construction and demolition waste other than } \\
\text { those mentioned in 17 09 01, 17 09 02 and 17 09 03 }\end{array}$ & 1.0 & non-hazardous \\
\hline
\end{tabular}

These requirements are usually linked to the renovation or demolition permit [42]. Additionally, it was necessary to process the material analysis of demolished construction parts. Non-load-bearing exterior cladding was a source of many construction materialstiles, ceramics, concrete, glass, steel, and cables. Inert concrete and electric cables were part of the internal non-load-bearing partition walls. The internal stairs and lift shafts were reinforced concrete structures, so they consisted mainly of concrete and steel. Preparatory works for increasing the depth of the foundation slab were focused on excavation work where the excavated soil was formed. The roof truss is a wooden construction and together with sheet metal roof covering are a material source of mainly wood and sheet metal. Spiroll panels are prefabricated reinforced concrete elements so they consist of concrete and steel. Demolition work was carried by demolition machinery. The disadvantage of mechanized demolition is the impossibility of selective waste separation. Therefore, mixtures of concrete, bricks, tiles, and ceramics represent the largest material flow.

The nature of demolition works affects the type of waste generated. Renovation works involved the complete demolition of the internal non-load-bearing partition walls and the complete demolition of internal stairs and lift shafts. Therefore, mixtures of concrete, bricks, tiles, and ceramics, and soil and stones represent the largest estimated share of generated waste for the solved construction.

For the purpose of economic analysis, CDW recovery were detected in its facilities in the Snina region (Table 7) as a part of desk study. Four recycling facilities (distance $40-110 \mathrm{~km})$ and two landfills $(28-73 \mathrm{~km}$ ) of CDW were near the places of CDW generation. The selected waste management facilities disposal uses only a specific type of CDW. The treatment fees vary depending on the type of CDW, the waste treatment method and treatment facility. The selected type of wastes (glass 1702 02, iron and steel 170405 and cables 170411 ) could be placed in the collection yard $5 \mathrm{~km}$ away from the construction site. There was no fee for their disposal.

The results of multiple visits of building and site (Figure 5) were the visual inspections and comparisons of construction conditions, with findings of the desk study.

During the building visits, photo documentation (Figure 6) was taken and measurements of the building were processed. As hazardous materials are not expected to be present, sampling and analysis of the hazardous substance in materials were irrelevant [38].

Inventory of materials is the most significant step of CDWA that determines the exact list of building materials and elements, their hazards and nature. The removed building material generates the construction waste. Thus, the properties of building materials predetermine the properties of CDW. The inventory of construction and demolition waste is summarized for the whole shopping center building (Table 8). 
Table 7. Waste management facilities in the Snina region.

\begin{tabular}{|c|c|c|c|c|}
\hline Facility & Distance (km) & $\begin{array}{c}\text { Code of Treated } \\
\text { CDW }\end{array}$ & $\begin{array}{l}\text { Type of Waste } \\
\text { Treatment }\end{array}$ & $\begin{array}{c}\text { Treatment Fee } \\
(€ / t)\end{array}$ \\
\hline \multirow{5}{*}{ A } & \multirow{5}{*}{40} & 170103 & \multirow{5}{*}{ recycling } & 5.00 \\
\hline & & 170107 & & 10.00 \\
\hline & & 170201 & & 20.00 \\
\hline & & 170504 & & 5.00 \\
\hline & & 170107 & & 20.00 \\
\hline \multirow[t]{2}{*}{ B } & \multirow[t]{2}{*}{98} & 170504 & \multirow{2}{*}{ recycling } & 15.00 \\
\hline & & 170904 & & 15.00 \\
\hline \multirow{3}{*}{$\mathrm{C}$} & \multirow{2}{*}{110} & 170107 & \multirow{2}{*}{ recycling } & 10.00 \\
\hline & & 170504 & & 10.00 \\
\hline & \multirow{4}{*}{82} & 170107 & & 10.00 \\
\hline \multirow{3}{*}{$\mathrm{D}$} & & 170201 & \multirow{3}{*}{ recycling } & 15.00 \\
\hline & & 170504 & & 5.00 \\
\hline & & 170904 & & 10.00 \\
\hline \multirow{8}{*}{$\mathrm{E}$} & \multirow{8}{*}{28} & 170103 & \multirow{8}{*}{ landfilling } & 46.80 \\
\hline & & 170107 & & 46.80 \\
\hline & & 170201 & & 30.00 \\
\hline & & 170202 & & 48.00 \\
\hline & & 170405 & & 30.00 \\
\hline & & 170411 & & 100.00 \\
\hline & & 170504 & & 12.00 \\
\hline & & 170904 & & 109.00 \\
\hline \multirow{4}{*}{$\mathrm{F}$} & \multirow{4}{*}{73} & 170107 & \multirow{4}{*}{ landfilling } & 49.00 \\
\hline & & 170201 & & 96.00 \\
\hline & & 170504 & & 16.60 \\
\hline & & 170904 & & 84.00 \\
\hline \multirow{3}{*}{ G } & & 170202 & \multirow{3}{*}{ collection yard } & 0.00 \\
\hline & 5 & 170405 & & 0.00 \\
\hline & & 170411 & & 0.00 \\
\hline
\end{tabular}

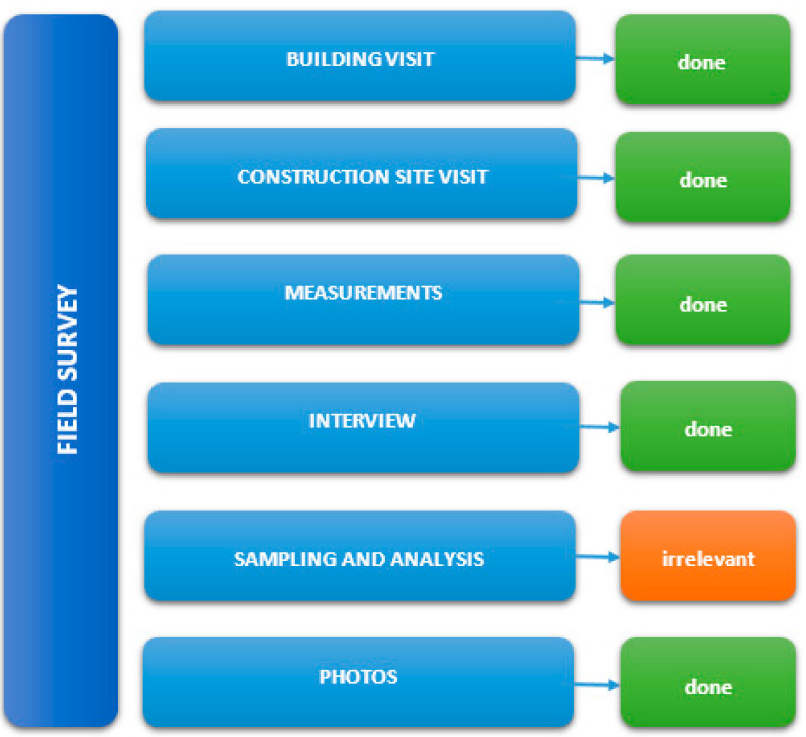

Figure 5. Steps of field survey for construction and demolition waste audit. 

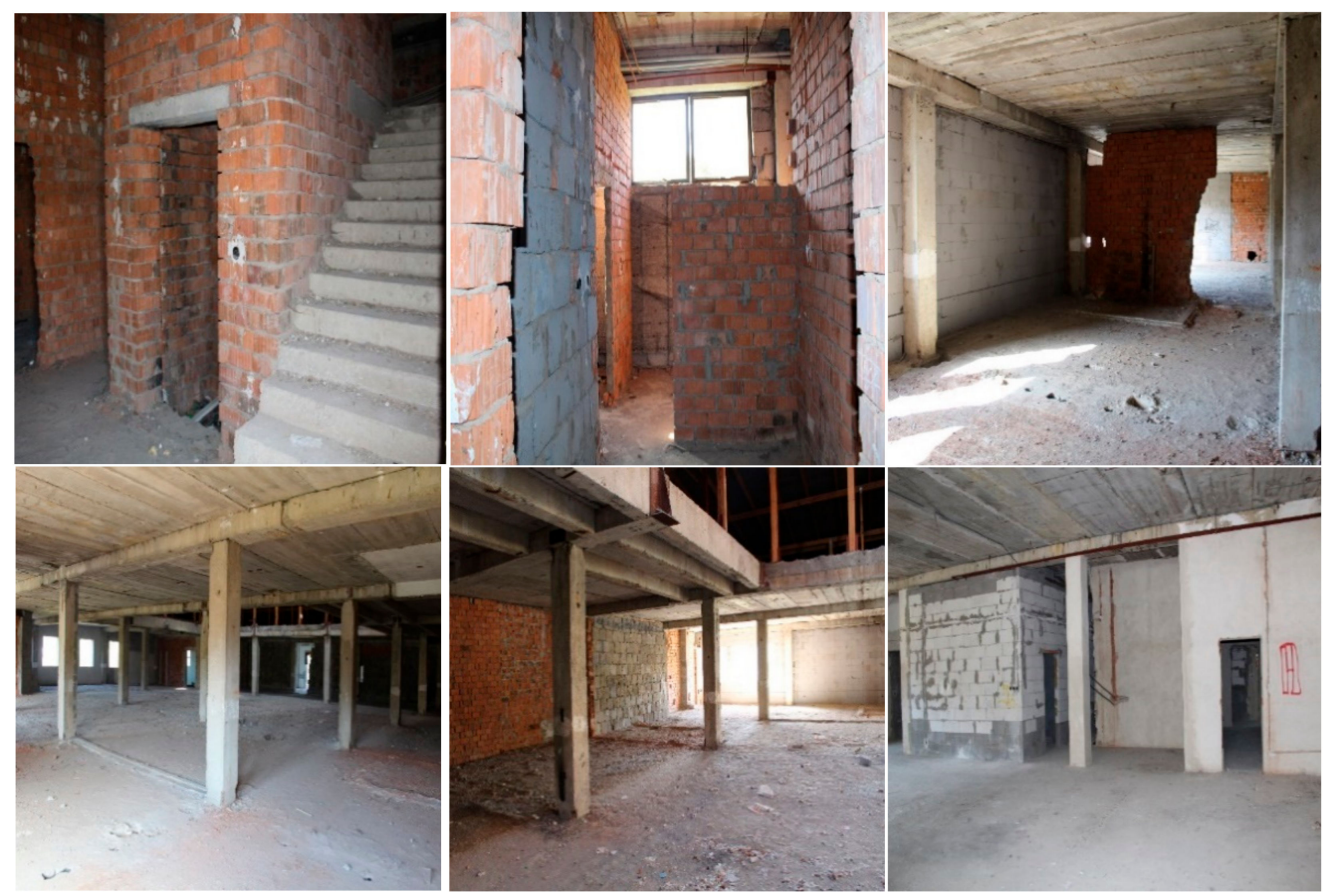

Figure 6. Photo documentation of the construction during the site visit.

Table 8. Inventory of construction and demolition waste.

\begin{tabular}{cccc}
\hline Type of Material & Type & Waste Code & Amount (t) \\
\hline inert waste & tiles and ceramics & 170103 & 1.5 \\
inert waste & mixtures of concrete, bricks, tiles and ceramics other & 170107 & 50.0 \\
inert waste & than those mentioned in 17 01 06 & 170201 & 1.0 \\
inert waste & wood & 170202 & 2.0 \\
inert waste & glass & 170405 & 1.2 \\
inert waste & cables other than those mentioned in 17 04 10 & 170411 & 0.05 \\
inert waste & soil and stones other than those mentioned in 17 05 03 & 170504 & 37.5 \\
inert waste & $\begin{array}{c}\text { mixed construction and demolition waste other than } \\
\text { those mentioned in 17 09 01, 17 09 02 and 17 09 03 }\end{array}$ & 170904 & 1.5 \\
\hline
\end{tabular}

Inventory of materials might differ from the estimated amount of CDW in the desk study. The accuracy of the estimate depends on the professional competence and skills of the person who proposed the estimate (designer of the construction project). The amount of CDW that originated, which was determined on the basis of the material inventory, was accurate. Actual amount of CDW was different compared to the estimated amount for soil and stones (less by $2.5 \mathrm{t}$ ), mixtures of concrete, bricks, tiles, and ceramics (more by $10 \mathrm{t}$ ), and mixed construction and demolition wastes (more by $0.5 \mathrm{t}$ ). The comparison proved to be significant to field surveys, when the building was inventoried on many occasions in a destructive manner.

All analyzed items were a non-hazardous inert waste material. A suitable method of this CDW management is recycling. The report of construction and demolition waste audit describes and determines the possible outlets for particular CDW type and recommended outlets (Table 9).

For many investors and contractors (as CDW holders or producers), the environmental benefits of waste recovery alone are not sufficient. The method of CDW treatment must have an economic effect. In order to confirm the economic benefits of CDW recovery, an economic analysis of possible ways of waste management was also performed. Variants A (waste management according to CDWA recommendation) and variant B (all types of CDW were landfilled) of waste management for all types of construction waste were compared. 
Table 9. Waste management recommendations.

\begin{tabular}{|c|c|c|c|c|}
\hline $\begin{array}{l}\text { Type of } \\
\text { Material }\end{array}$ & Waste Code & Amount (t) & Possible Outlets & $\begin{array}{l}\text { Recommended } \\
\text { Outlets }\end{array}$ \\
\hline inert waste & 170103 & 1.5 & $\begin{array}{l}\text { A-recycling } \\
\text { E-landfilling }\end{array}$ & E-landfilling \\
\hline inert waste & 170107 & 50 & $\begin{array}{l}\text { A-recycling } \\
\text { E-landfilling }\end{array}$ & A-recycling \\
\hline inert waste & 170201 & 1.0 & $\begin{array}{l}\text { A-recycling } \\
\text { E-landfilling }\end{array}$ & A-recycling \\
\hline inert waste & 170202 & 2.0 & $\begin{array}{c}\text { E-landfilling } \\
\mathrm{G} \text {-collection yard }\end{array}$ & $\mathrm{G}$-collection yard \\
\hline inert waste & 170405 & 1.2 & $\begin{array}{c}\text { E-landfilling } \\
G-\text { collection yard }\end{array}$ & $\mathrm{G}$-collection yard \\
\hline inert waste & 170411 & 0.05 & $\begin{array}{c}\text { E-landfilling } \\
\mathrm{G} \text {-collection yard }\end{array}$ & $\mathrm{G}$-collection yard \\
\hline inert waste & 170504 & 37.5 & $\begin{array}{c}\text { A-recycling } \\
\text { E-landfilling }\end{array}$ & A-recycling \\
\hline inert waste & 170904 & 1.5 & $\begin{array}{l}\text { A-recycling } \\
\text { E-landfilling }\end{array}$ & A-recycling \\
\hline
\end{tabular}

Economic potential proving of CDWA processing was realized using Equations (1)-(4). The calculation of costs for individual variants of waste disposal confirmed the significant economic effect of a sustainable method (recommended by CDWA) of CDW disposal. The cost of recovering CDW according to waste audit recommendations was $878.50 €$ (Table 10).

Table 10. Economic analysis of waste management according to CDW recommendation-variant A.

\begin{tabular}{ccccc}
\hline Waste Code & $\begin{array}{c}\text { Recommended } \\
\text { Outlets }\end{array}$ & Amount (t) & $\begin{array}{c}\text { Treatment Fee } \\
(\boldsymbol{\epsilon} / \mathbf{t})\end{array}$ & $\begin{array}{c}\text { Total Treatment } \\
\text { Fee }(\boldsymbol{\epsilon})\end{array}$ \\
\hline 170103 & A-recycling & 1.5 & 5 & 7.50 \\
170107 & A-recycling & 50 & 10 & 500 \\
170201 & A-recycling & 1.0 & 20 & 20 \\
170202 & G-collection yard & 2.0 & 0 & 0 \\
170405 & G-collection yard & 1.2 & 0 & 0 \\
170411 & G-collection yard & 0.05 & 0 & 0 \\
170504 & A-recycling & 37.5 & 5 & 187.50 \\
170904 & E-landfilling & 1.5 & 109.00 & 163.50 \\
& TOTAL & & & $878.50 €$ \\
\hline
\end{tabular}

Fees for a sustainable method of waste treatment were up to $72.5 \%$ lower than if we landfill the generated waste for the reconstruction of the shopping center in Snina only in a construction waste landfill (3190.70 €) (Table 11).

Table 11. Economic analysis of waste management by landfilling-variant B.

\begin{tabular}{ccccc}
\hline Waste Code & $\begin{array}{c}\text { Recommended } \\
\text { Outlets }\end{array}$ & Amount $(\mathbf{t )}$ & $\begin{array}{c}\text { Treatment Fee } \\
(\boldsymbol{(} / \mathbf{t})\end{array}$ & $\begin{array}{c}\text { Total Treatment } \\
\text { Fee }(\boldsymbol{\epsilon})\end{array}$ \\
\hline 170103 & E-landfilling & 1.5 & 46.80 & 70.20 \\
170107 & E-landfilling & 50 & 46.80 & 2340 \\
170201 & E-landfilling & 1.0 & 30 & 30 \\
170202 & E-landfilling & 2.0 & 48 & 96 \\
170405 & E-landfilling & 1.2 & 30 & 36 \\
170411 & E-landfilling & 0.05 & 100 & 5 \\
170504 & E-landfilling & 37.5 & 12 & 450 \\
170904 & E-landfilling & 1.5 & 109.00 & 163.50 \\
& TOTAL & & $3190.70 \boldsymbol{\epsilon}$ \\
\hline
\end{tabular}


Of course, it is also necessary to assess the transport costs of individual variants using Equations (2)-(4). Transport costs of variant A 134,375 $€$ and variant B were 119,000 $€$. The transport costs depended mainly on the distance of the waste disposal site from the waste generation site. Higher transport distance between recycling center A and the waste generation site in Snina also affected the higher transport costs of variant A.

Costs for waste recovery of individual variants changed after taking into account transport costs in the calculation. The total costs (disposal and transport) of waste recovery for the recommended method (variant A) were $222,225 €$, and for variant B it was $438,070 €$. Even after taking into account transport costs, an environmentally suitable solution was $49.5 \%$ more cost-effective than landfilling even though the landfill was closer than the recycling facility. Therefore, it should be noted that suitable proposal for utilization of transport capacity of vehicles could reduce transport costs and the negative environmental effects of transport for both variants. This is possible through the application of principles of lean logistics. For example, by applying the lean principle, it is possible to use "Milk run" for the full transport capacity of vehicle. Improving the information flow about the vehicle transport capacity can be achieved by the lean principle "Vendor managed inventory" [43].

An important part of the economic assessment of construction waste recycling is also consideration of selling prices of recovered materials. The authors of study [11] confirmed that material reuse has the potential to become a price-competitive production practice. In some cases, recycled material is significantly cheaper than raw material. For example, recycled concrete is about $40 \%$ cheaper than the raw material [44]. These considerations support economic feasibility and sustainability of building dismantling.

Finally, it should be noted that a similar environmental and economic comparison can be made through buildings information modeling (BIM) [45]. Another dimension of information in BIM could relate to the cost parameters of selected waste disposal methods, which might be the subject of further research. Building information modeling, parametric modeling, or visualization could improve the efficiency of CDW management planning in many aspects. Correctly implemented CDWA would significantly contribute to the sustainability of construction, total quality management systems, and reducing the impact of the construction sector to the environment [46-50]. Moreover, the audit has an unquestionable place in the sustainable design of construction because it affects all three dimensions (economic, social, and environmental) of sustainable construction projects and is in accordance with the newest trends of EU.

\section{Conclusions}

The construction sector has a huge potential for reducing waste. Most construction and demolition waste is not hazardous and is therefore suitable for recovery. The undeniable fact is that there are currently many barriers to the proper management of CDW. Additionally, different approaches to the management of CDW are noticeable between the EU member states. The recovery rate between EU member states differs significantly from one country to another. Therefore, the European Union took a number of measures, including "Guidelines for waste audits before demolition and renovation works of buildings" [38]. The document is focused on assessment of CDW streams prior to renovation of demolition of constructions. Slovakia does not belong to leaders in construction and demolition of waste recovery. On the contrary, Slovakia is one of the few countries not meeting the EU target of 70\% of CDW reused, recycled, or recovered by 2020 [14].

The presented case study provides the processing of a construction and demolition waste audit before the realization of renovation works on the building of a shopping center in Snina, a town in Northeastern Slovakia. The report of CDWA describes and determines the possible outlets for particular CDW type and recommended outlets. The recommended outlets prefer mainly a CDW recycling. A very common practice in Slovakia is that most originated construction waste is landfilled. The second part of the paper provides an economic analysis of two variants of waste disposal. Variant A presents waste management according to the CDWA recommendation; and Variant B presents the least 
environmentally friendly method of waste management, namely landfilling of the whole volume of waste. The comparison of costs for waste recovery and transport costs of both variants confirmed the economic benefit of waste recovery according to recommended outlets in CDWA. The environmentally suitable recommended solution was $49.5 \%$ more cost-effective than landfilling, even though the landfill was closer than the recycling facility. Of course, such economic efficiency was expressed only for the present case study. The result cannot be generalized. On the other hand, the methodology of solving a case study represents a procedure that could also be implemented in building information modeling. Another dimension of information in BIM could relate to the cost parameters of selected waste disposal methods, which might be the subject of further research.

Author Contributions: The individual contributions of authors were as follows: M.S. writingoriginal draft preparation, conceptualization, literature review, methodology, data processing; P.M.: writing-review and editing, supervising; T.M.: literature review, methodology. All authors have read and agreed to the published version of the manuscript.

Funding: This work was supported by the Slovak Research and Development Agency under contract no. APVV-17-0549. The article presents a partial research result of project KEGA 059TUKE-4/2019, "M-learning tool for intelligent modelling of site structure parameters in a mixed reality environment". This paper presents partial research results of project VEGA 1/0557/18 Research and development of process and product innovations of modern methods of construction in the context of the Industry 4.0 principles.

Institutional Review Board Statement: Not applied.

Informed Consent Statement: Not applied.

Data Availability Statement: Not applied.

Conflicts of Interest: The authors declare no conflict of interest.

\section{References and Note}

1. European Commission. Strategy for the Sustainable Competitiveness of the Construction Sector and Its Enterprises; Communication from the Commission to the European Parliament and the Council: Brussels, Belgium, 2012.

2. Jin, R.; Yuan, H.; Chen, Q. Science mapping approach to assisting the review of construction and demolition waste management research published between 2009 and 2018. Resour. Conserv. Recycl. 2019, 140, 175-188. [CrossRef]

3. Ridwana, I.; Nassif, N.; Choi, W. Modeling of building energy consumption by integrating regression analysis and artificial neural network with data classification. Buildings 2020, 10, 198. [CrossRef]

4. European Commission. Closing the Loop-An EU Action Plan for the Circular Economy. Communication from the Commission to the European Parliament, the Council, the European Economic and Social Committee and the Committee of the Regions; European Commission: Brussels, Belgium, 2015.

5. Eurostat, Waste Statistics. Available online: https:/ / ec.europa.eu/eurostat/statistics-explained/index.php/Waste_statistics\# Total_waste_generation (accessed on 5 September 2020).

6. Advancing Sustainable Materials Management: 2014 Fact Sheet. Available online: https://www.epa.gov/sites/production/files/ 2016-11/documents/2014_smmfactsheet_508.pdf (accessed on 11 August 2020).

7. Huang, B.; Wang, X.; Kua, H.; Geng, Y.; Bleischwitz, R.; Ren, J. Construction and demolition waste management in China through the 3R principle. Resour. Conserv. Recycl. 2018, 129, 36-44. [CrossRef]

8. Gálvez-Martos, J.-L.; Styles, D.; Schoenberger, H.; Zeschmar-Lahl, B. Construction and demolition waste best management practice in Europe. Resour. Conserv. Recycl. 2018, 136, 166-178. [CrossRef]

9. Osmani, M.; Villoria-Sáez, P. Current and emerging construction waste management status, trends and approaches. In Waste, 2nd ed.; Letcher, T.M., Vallero, D.A., Eds.; Elsevier Inc.: Amsterdam, The Netherlands, 2019; pp. 365-380.

10. Arm, M.; Wik, O.; Engelsen, C.J.; Erlandsson, M.; Hjelmar, O.; Wahlstrom, M. How Does the European Recovery Target for Construction \& Demolition Waste Affect Resource Management? Waste Biomass Valor. 2017, 8, 1491-1504.

11. Ginga, C.P.; Ongpeng, J.M.C.; Daly, M.K.M. Circular Economy on Construction and Demolition Waste: A Literature Review on Material Recovery and Production. Materials 2020, 13, 2970. [CrossRef] [PubMed]

12. Chen, J.; Su, Y.; Si, H.; Chen, J. Managerial Areas of Construction and Demolition Waste: A Scientometric Review. Int. J. Environ. Res. Public Health 2018, 15, 2350. [CrossRef]

13. Eurostat 2020, Recovery Rate of Construction and Demolition Waste. Available online: https://ec.europa.eu/eurostat/web/ products-datasets / product?code=cei_wm040 (accessed on 10 September 2020). 
14. Directive 2008/98/EC of the European Parliament and of the Council of 19 November 2008 on waste and repealing certain Directives.

15. European Commission. EU Construction E Demolition Waste Management Protocol; European Commission: Brussels, Belgium, 2016.

16. Mahpour, A. Prioritizing barriers to adopt circular economy in construction and demolition waste management. Resour. Conserv. Recycl. 2018, 134, 216-227. [CrossRef]

17. Crawford, R.H.; Mathur, D.; Gerritsen, R. Barriers to improving the environmental performance of construction waste management in remote communities. Procedia Eng. 2017, 196, 830-837. [CrossRef]

18. Abarca-Guerrero, L.; Maas, G.; van Twillert, H. Barriers and motivations for construction waste reduction practices in Costa Rica. Resources 2017, 6, 69. [CrossRef]

19. Dumlao-Tan, M.I.; Halog, A. Chapter 2. Moving Toward a Circular Economy in Solid Waste Management. In Advances in Solid and Hazardous Waste Management: Concepts and Practices, 1st ed.; Goel, S., Ed.; Springer International Publishing: New York, NY, USA, 2017; pp. 29-48.

20. Veleva, V.; Bodking, G.; Todorova, S. The need for better measurement and employee engagement to advance a circular economy: Lessons from Biogen's "Zero Waste". J. Clean. Prod. 2017, 154, 517-529. [CrossRef]

21. Ranta, V.; Aarikka-Stenroos, L.; Ritala, P.; Mäkinen, S.J. Exploring institutional drivers and barriers of the circular economy: A cross-regional comparison of China, the US, and Europe. Resour. Conserv. Recycl. 2018, 135, 70-82. [CrossRef]

22. Singh, J.; Ordonez, I. Resource recovery from post-consumer waste: Important lessons for the upcoming circular economy. $J$. Clean. Prod. 2016, 134, 342-353. [CrossRef]

23. Lee, J.; Pedersen, A.B.; Thomsen, M. Are the resource strategies for sustainable development sustainable? Downside of a zero waste society with circular resource flows. Environ. Technol. Innov. 2014, 1, 46-54. [CrossRef]

24. Hossain, M.U.; Wu, Z.; Poon, C.S. Comparative environmental evaluation of construction waste management through different waste sorting systems in Hong Kong. Waste Manag. 2017, 69, 325-335. [CrossRef] [PubMed]

25. Esa, M.R.; Halog, A.; Rigamonti, L. Developing strategies for managing construction and demolition wastes in Malaysia based on the concept of circular economy. J. Mater. Cycles Waste Manag. 2016, 19, 1144-1154. [CrossRef]

26. Mittal, V.K.; Sangwan, K.S. Prioritizing barriers to green manufacturing: Environmental, social and economic perspectives, variety management in manufacturing. Procedia CIRP 2014, 17, 559-564. [CrossRef]

27. Abba, A.H.; Noor, Z.Z.; Yusuf, R.O.; Din, M.F.M.D.; Hassan, M.A.A. Assessing environmental impacts of municipal solid waste of Johor by analytical hierarchy process. Resour. Conserv. Recycl. 2014, 73, 188-196. [CrossRef]

28. Li, J.; Yu, K. A study on legislative and policy tools for promoting the circular economic model for waste management in China. $J$. Mater. Cycles Waste Manag. 2011, 13, 103-112. [CrossRef]

29. Ritzén, S.; Sandström, G.Ö. Barriers to the circular economy-integration of perspectives and domains. Procedia CIRP 2017, 64, 7-12. [CrossRef]

30. Yong, D. Plant location selection based on fuzzy TOPSIS. Int. J. Adv. Manuf. Technol. 2006, 28, 839-844. [CrossRef]

31. Yuan, H. Barriers and countermeasures for managing construction and demolition waste: A case of Shenzhen in China. J. Clean. Prod. 2017, 157, 84-93. [CrossRef]

32. Nakajima, S.; Russell, M. Barriers for deconstruction and reuse/recycling of construction materials. In International Council for Research and Innovation in Building and Construction (CIB); Working Commission W115, Construction Materials Stewardship: Gainesville, FL, USA, 2014.

33. Yuan, H.; Shen, L.; Wang, J. Major obstacles to improving the performance of waste management in China's construction industry. Facilities 2011, 29, 224-242. [CrossRef]

34. Teo, M.M.M.; Loosemore, M. A theory of waste behavior in the construction industry. Constr. Manag. Econ. 2001, 19, 741-751. [CrossRef]

35. Kuijsters, A. Environmental Response of the Chilean Building Sector. Master's Thesis, Eindhoven University of Technology, Eindhoven, The Netherlands, 2004.

36. Manowong, E. Investigating factors influencing construction waste management efforts in developing countries: An experience from Thailand. Waste Manag. Res. 2012, 30, 56-71. [CrossRef]

37. Osmani, M.; Glass, J.; Price, A.D.F. Architects' perspectives on construction waste reduction by design. Waste Manag. 2008, 28, 1147-1158. [CrossRef]

38. European Commission. Guidelines for the Waste Audits before Demolition and Renovation Works of Buildings; EU Construction and Demolition Waste Management: Brussels, Belgium, 2018.

39. Monier, V.; Hestin, M.; Impériale, A.; Prat, L.; Hobbs, G.; Adams, K.; Pairon, M.; de Winghe, M.R.; Wiaux, F.; Wahlström, M.; et al. Resource Efficient Use of Mixed Wastes Improving Management of Construction and Demolition Waste. 2017. Available online: https:/ / ec.europa.eu/environment/waste/studies/pdf/CDW_Final_Report.pdf (accessed on 9 September 2020).

40. Wahlström, M. Improving Quality of Construction \& Demolition Waste-Requirements for Pre-Demolition Audit; Nordic Council of Ministers: Copenhagen, Denmark, 2019.

41. Commission Decision 2014/955/EU, of 18 December 2014 Amending Decision 2000/532/EC on the List of Waste Pursuant to Directive 2008/98/EC of the European Parliament and of the Council; Official Journal of the European Union: Brussels, Belgium, 2014. 
42. Gasparik, J.; Funtik, T.; Gasparik, M.; Alamro, B. Continuing increasing of quality management level in construction company using excellence model with software support. In Proceedings of the ISARC 2018 - 35th International Symposium on Automation and Robotics in Construction and International AEC/FM Hackathon: The Future of Building Things, Berlin, Germany, 10-25 July 2018; Elsevier: Amsterdam, The Netherlands, 2020.

43. Spisakova, M.; Kozlovska, M. Implementation of lean production in construction-Case study. In ESaT 2018 - Advances and Trends in Engineering Sciences and Technologies III-Proceedings of the 3rd International Conference on Engineering Sciences and Technologies, Vysoké Tatry, Slovakia, 12 September 2018; CRC Press/Balkema: Leiden, The Netherlands, 2018.

44. Nusholz, J.L.K.; Rasmussen, F.N.; Whalen, K.; Plypes, A. Material reuse in buildings: Implications of a circular business model for sustainable value creation. J. Clean. Prod. 2020, 245, 118546. [CrossRef]

45. Wijewickrama, M.K.C.; Chileshe, N.; Rameezdeen, R.; Ochoa, J.J. Quality assurance in reverse logistics supply chain of demolition waste: A systematic literature review. Waste Manag. Res. 2020, 106, 1-22. [CrossRef] [PubMed]

46. Kafel, K.; Lesniak, A.; Zima, K. Multicriteria comparative analysis of pillars strengthening of the historic building. Open Eng. 2019, 9, 18-25. [CrossRef]

47. Act No. Ministry of Transport and Construction of the Slovak Republic 50/1976 Act on Spatial Planning and Building Regulations; Legislation: Bratislava, Slovakia, 1976.

48. Spišáková, M.; Kozlovská, M. Waste reduction through using modern methods of construction. Waste Forum $2019,4,361-367$.

49. Guerra, B.C.; Leite, F.; Faus, K.M. 4D-BIM to enhance construction waste reuse and recycle planning: Case studies on concrete and drywall waste streams. Waste Manag. 2020, 116, 79-90. [CrossRef] [PubMed]

50. Venkrbec, V.; Klanšek, U. Suitability of recycled concrete aggregates from precast panel buildings deconstructed at expired lifespan for structural use. J. Clean. Prod. 2020, 247, 119593. [CrossRef] 